\title{
Late Holocene paleoenvironmental changes in Northeast Brazil recorded by organic matter in lacustrine sediments of Lake Boqueirão.
}

\author{
Zocatelli, R.,.$^{\text {a,b,c,f*; }}$;urcq, B, ${ }^{\text {d,f }}$; Boussafir, M. ${ }^{\text {a,b,c,f }}$; Cordeiro, R.C. ${ }^{\text {e,f }}$ Disnar, \\ J.R. ${ }^{\text {a,b,c }}$; Costa, R.L. ${ }^{\text {e,f }}$; Sifeddine, A. ${ }^{\text {de,ff; }}$ Albuquerque, A.L.S..$^{\text {e,f }}$; \\ Bernardes, M.C. ${ }^{\text {e,f }}$; Jacob, J. ${ }^{\text {a,b,c }}$. \\ a'Université d'Orléans, ISTO, UMR, 7327, 45071, Orléans, France \\ ${ }^{\mathrm{b}}$ CNRS/INSU, ISTO, UMR 7327, 45071, Orléans, France \\ ${ }^{c}$ BRGM, ISTO, UMR 7327, BP 36009, 45060, Orléans, France \\ ${ }^{\mathrm{d}}$ LOCEAN-IPSL (CNRS/IRD/UPMC/MNHN), Centre IRD France-Nord, Bondy, France. \\ ${ }^{e}$ Universidade Federal Fluminense, Morro do Valonguinho s/n, Departamento de Geoquímica, Niterói, \\ Rio de Janeiro, Brazil. \\ fLMI "PALEOTRACES" (Paléoclimatologie tropicale: TRACEurs et VariabilitéS) (IRD-UFF-UANTOF)
}

\begin{abstract}
Northeast Brazil represents a key area in terms of Holocene environmental changes in South America due to its distinct semi-arid climate at near equatorial latitudes as well as to a wetter Early and Middle Holocene paleoclimate in comparison with other South America regions, which also experienced a reduced monsoon at that time. We studied the lacustrine sediments of Lake Boqueirão, which is located at $5^{\circ} \mathrm{S}$ latitude on the Brazilian Atlantic coast; it is directly influenced by displacement of the Intertropical Convergence Zone (ITCZ). A short (1 m) core "Boqc0701" was collected at a $7.5 \mathrm{~m}$ water depth during a seismic survey. Organic matter (OM) geochemical [Rock Eval Total Organic Carbon (TOC), Hydrogen Index (HI), Oxygen Index (OI)] and petrographical studies allowed us to distinguish five sedimentary intervals during the last 3 kyrs. Phase E (3000 to 2050 cal yr BP) presents the largest TOC, HI and OI fluctuations in the entire core. The most probable cause of these variations is a great instability in the lake level during this period. Phase D (2050 to $1830 \mathrm{cal} \mathrm{yr} \mathrm{BP}$ ) is marked by an increase in sedimentation rate and a higher contribution from a wellpreserved $\mathrm{OM}$ with an algal origin; this was interpreted as a higher and more stable lake level. During phase C (1830 to 1550 cal yrs BP), low HI and high OI indicate the input of more oxidized, degraded and detrital OM, reflecting a lower lake level. In phase B (1550 to 1470 cal yr BP), the OM quality and quantity (HI and TOC) indicate an algal contribution. During phase A (1470 to 570 cal yr BP), the high stability of the proxies may be due to a deep environment where OM fluctuations are strongly buffered. These changes in lake level can be compared with other tropical South America high resolution records. A correspondence seems to exist between phases of low ENSO, cool North Atlantic Ocean and Boqueirão wet phases. We did not encounter this same pattern during the last 1050 yaers, during which the 1050-570 cal yrs BP interval was generally wet (although probable fluctuations are buffered in our proxies) while the North Atlantic was warm (Mann et al., 2009). A prolonged dryness occurred in Lake Boqueirão from 570 cal yrs BP until recent decades. This phase corresponds to the Little Ice Age characterized by a cooler North Atlantic Ocean (Mann et al., 2009). These data indicate that the teleconnection pattern between the tropical Atlantic, ENSO and Northeast Brazil rainfalls has changed in the past.
\end{abstract}


Keywords: Rock-Eval, organic petrography, macrophytes, algal, intertropical convergence.

\section{Introduction}

Recurrent droughts have severe socio-economic impacts on the semi-arid region of Northeast Brazil, especially in terms of health and nutrition due to the unstable availability of water (CEPALC, 2009). Drought occurrences show an interannual variability linked to the Tropical Atlantic Sea Surface Temperature (SST, Nobre \& Shukla, 1996). In drought years, pre-season rainfall (October-January) is scarce, the interhemispheric SST gradient is weak and the basin-wide northerly wind component is reduced, which results in an anomalously far northward repositioning of the Intertropical Convergence Zone (ITCZ) (Hastenrath, 2006). From a more general standpoint, Northeast Brazil represents a key area in terms of Quaternary records of environmental changes in South America due to its distinct semi-arid climate at near equatorial latitudes. Paleoclimate studies have shown that the Northeastern part of Brazil is influenced by variations in insolation and is sensitive to abrupt climate change during the Late Glacial (Arz et al., 1999, 2007; Cheng et al., 2009; Cruz et al., 2009). However, climate variability in this region during more recent times, especially the Late Holocene, is still poorly studied (e.g., Mann et al., 2009). In an attempt to fill this gap, we studied the lacustrine sediments of Lake Boqueirão, which is located at $5^{\circ} \mathrm{S}$ latitude on the Brazilian Atlantic coast and is directly influenced by the ITCZ's displacement. The aim of this paper is to present and discuss information about the palaeoenvironmental records of Lake Boqueirão from bulk and petrographic analyses of sedimentary organic matter $(\mathrm{OM})$ during the last $3 \mathrm{kyr}$. $\mathrm{OM}$ abundance and origin are discussed in terms of sources, diagenesis and temporal fluctuations.

\section{Study Site}

Lake Boqueirão is located in Northeastern Brazil (State of Rio Grande do Norte) approximately $8 \mathrm{~km}$ from the Atlantic coast ( $5^{\circ} 14^{\prime} 57.1^{\prime \prime} \mathrm{S}, 35^{\circ} 32^{\prime} 42.5^{\prime \prime} \mathrm{W}$, Fig. 1a). The catchment area occupies a small basin, which is approximately $250 \mathrm{~km}^{2}$ with poor runoff. The surrounding landscape is composed of Mesozoic and cenozoic clastic consolidated sediments from the sandy Barreiras formation (sandstones from deltaic continental environment, CPRM, 2012). The creation of the lake occurred when Pleistocene beach ridges dammed a small river. The local present-day climate is tropical 
semi-humid with pronounced seasonality linked to seasonal changes in the ITCZ. Precipitation occurs during the rainy season from November to May (800 mm.yr ${ }^{-1}$, approximately), and the mean annual temperature is $27^{\circ} \mathrm{C}$. The maximum water depth is $10 \mathrm{~m}$ during the wet season (austral summer) and $9 \mathrm{~m}$ during the dry season (austral winter). Modern vegetation in NE Brazil is primary caatinga (IBGE, 1993), which is subdivided into several physiognomic vegetation types, from grassland to xerophytic thorn shrub savanna, and shrub woodland (Cole, 1960; Eiten, 1982). At present, the dominant natural vegetation of the region is grass steppe (Restinga). The lake is oligotrophic and surrounded by agricultural lands with intensive cultivation of grass (Zocatelli et al., 2010), fruits and vegetables (Fig. 1a).

\section{Sampling and Methods}

\subsection{Sampling}

Thirty-eight seismic transects were performed at Lake Boqueirão, using a StrataBox ${ }^{\mathrm{TM}}$ Marine Geophysical Instrument with a wave frequency of $10 \mathrm{kHz}$. The seismic data were used to estimate the bathymetry and to choose the appropriate sampling sites for coring. Here, we report the results of a $1 \mathrm{~m}$-long core (Boqc0701) collected by a diver using an acrylic tube. The core was sliced every $0.5 \mathrm{~cm}$. Before analysis, the sediments were dried at $40{ }^{\circ} \mathrm{C}$ in an oven and ground with a mortar.

\subsection{Bulk organic geochemistry analyses}

\subsubsection{Dating}

AMS radiocarbon dating was determined on the total OM from fifteen samples at the Laboratoire de Mesures $d u{ }^{14} C$, Saclay, France. The radiocarbon ages were calibrated by using the program CALIB 5.02 (Stuiver et al., 2009). We considered the probability peak of the calibration curve in each 2-sigma $(2 \sigma)$ interval to calculate the age model based on cubic spline interpolations (Fig. 1). Eleven samples taken at $10 \mathrm{~cm}$ depth interval from the top of core were analyzed for ${ }^{210} \mathrm{~Pb}$ at the Laboratory of Radioecology and Global Changes (LARAMG) at the Universidade Estadual do Rio de Janeiro (UERJ), Brazil. All the samples below $10.5 \mathrm{~cm}$ have no activity indicating that the top of the core is less than $\sim 100$ years old. 


\subsubsection{Organic petrography}

Extracts were prepared from approximately $0.5 \mathrm{~g}$ of sediment and treated with both $\mathrm{HCl}$ and $\mathrm{HF}$ to remove the mineral matrix. The $\mathrm{OM}$ concentrates were diluted in 5 $\mathrm{ml}$ of $\mathrm{H}_{2} \mathrm{O}$, and an aliquot of $5 \mu \mathrm{l}$ was used for the thin plate assembly. The organic residues were then observed under natural transmitted light with a LEICA DMR XP microscope. Over 1000 microscopic fields were counted to estimate the relative proportions of each organic fraction. The count was completed after obtaining standard deviation values $\leq 1 \%$ for each group of particles. Identification of hydrocarbon-rich particles was achieved under UV excitation. The first criterion for quantification is the identification of recognizable biological structures (Fig. 2). Translucent and partly amorphized ligno-cellulosic debris (AmLC) was derived from slightly decomposed vascular plant tissues. These fragments originated mainly from aquatic macrophytes (Hui et al., 1995); membranes from their tissues had settled in the water column and were rapidly incorporated into the sediments (Turcq et al., 2002). Opaque lignocellulosic (LCO) fragments from watershed vegetation were oxidized in the soil or during transport to the lake (Sifeddine et al., 1994, Patience et al., 1995; Turcq et al., 2002). The last type of particle is composed of structure less material and is referred to as Amorphous OM (AOM). Patience et al. (1995) identified flocculated amorphous organic material (FlAOM) and concluded, according to molecular investigation, an autochthonous aquatic origin for this OM. Gelified amorphous OM (GelAOM) is derived from watershed soils (Sifeddine et al., 1994, 1995, 1996; Patience et al., 1995). The total carbon content was measured by combustion with an Elementar (Vario EL III) analyzer.

\subsubsection{Rock-Eval analysis}

Approximately 60 to $100 \mathrm{mg}$ of dried sediments were analyzed in a Rock-Eval Turbo6 (Vinci Technologies). The pyrolysis program was as follows: $2 \mathrm{~min}$ at $200^{\circ} \mathrm{C}$, raised to $650{ }^{\circ} \mathrm{C}$ in $30{ }^{\circ} \mathrm{C} \cdot \mathrm{min}^{-1}$ increments and held for $3 \mathrm{~min}$ at this temperature. The oxidation phase, which was performed in a second oven under an air stream, began with an isothermal stage at $400{ }^{\circ} \mathrm{C}$, then increased to $650{ }^{\circ} \mathrm{C}\left(30^{\circ} \mathrm{C} \cdot \mathrm{min}^{-1}\right)$ and was held for 5 min at this temperature. The Rock-Eval parameters used in this study were as follows: (i) the Total Organic Carbon (TOC, \%); (ii) the Hydrogen Index (HI, in mgHC.g ${ }^{-1}$ TOC) is the amount of hydrocarbonaceous (HC) products released during pyrolysis divided by 
the TOC; and (iii) the Oxygen Index (OI, in $\mathrm{mgCO}_{2} \cdot \mathrm{g}^{-1} \mathrm{TOC}$ ) which gives the oxygen content of the $\mathrm{OM}$, which was calculated from the amounts of $\mathrm{CO}(\mathrm{S} 3 \mathrm{CO})$ and $\mathrm{CO}_{2}$ $\left(\mathrm{S}_{3} \mathrm{CO}_{2}=\mathrm{S} 3\right)$ released during pyrolysis and normalized to the TOC (Lafargue et al., 1998).

\subsubsection{Description of the Rock-Eval parameters:}

Espitalié et al. (1977) identified three main types of non-altered- OM from HI and OI parameters (following the classical pseudo-van Krevelen diagram): (i) type I originates from hydrogen-rich and oxygen-depleted lacustrine algal OM; (ii) type II corresponds to mixed OM in lacustrine sites; (iii) type III is typical of an oxygen-rich and hydrogen-poor OM derived from lignin-rich higher plant materials. S2 vs. TOC and S3 vs. TOC diagrams can be used to characterize the origin and preservation, respectively, of different units within the same sediment core (Langford and BlancValleron, 1990; Sebag et al., 2006; Jacob et al., 2004). S2 pick produced during the pyrolysis cycle indicates the hydrocarbon contents $(\mathrm{HC})$, reflecting the preservation state of OM. S3 corresponds to the amount of $\mathrm{CO}_{2}$ produced between 200 and $400{ }^{\circ} \mathrm{C}$ during the cycle of pyrolysis. The integration limit was set at $400{ }^{\circ} \mathrm{C}$ to prevent the integration of $\mathrm{CO}_{2}$ from carbonates.

\section{Results}

\subsection{Seismic profiles and dating}

Thirty-eight seismic profiles from Lake Boqueirão's deposits showed no evidence of neotectonic perturbation or discordance (Fig. 1b). Two depositional zones were recognized: one in the center and one near the lake's margin. In the center, the seismic profile of the sampling area indicated a $4 \mathrm{~m}$ thick clear band. The $1 \mathrm{~m}$ long Boqc0701 core was taken from the center of the lake. The Boqc0701 sediment was homogeneous dark organic clay that showed no lithological variations. The radiocarbon ages showed that the sedimentation was continuous from 3000 to $470-590 \mathrm{cal}$ yrs BP $(99-21 \mathrm{~cm}$,

Fig. 1c). Two samples, at 2.5 and $8 \mathrm{~cm}$ depth have ${ }^{14} \mathrm{C}$ activities of $102 \pm 0,3$ and 106 $\pm 0,3 \%$ of modern carbon respectively, indicating that these levels are younger than 1950. The ${ }^{210} \mathrm{~Pb}$ analysis indicated that there is no more ${ }^{210} \mathrm{~Pb}$ excess (unsupported) below $11 \mathrm{~cm}$, confirming that only the top of the core is very recent. Thus, a sedimentation hiatus occurred from around 570 cal yrs BP up until the past few decades. People living in the area say that the present-day lake formed around 50 yrs ago. 
Topmost, recent sediment sedimentation has been discussed elsewhere (Zocatelli et al., 2010) and will not be discussed in this work. The top of the sediment below the hiatus may have been subject to erosion and/or bioturbation, 570 cal yrs BP is therefore a high estimate for the sedimentation break.

\subsection{Characterization of the sedimentary Organic Matter}

The variations in the geochemical data (TOC, HI, OI and TC account for the organic and mineral carbon as well) and the organic petrography counts allowed us to identify five sedimentological phases during the last 3000 cal yr (Fig. 3).

Phase E (3000 to 2050 cal yr BP) was characterised by the highest variability of all the Rock-Eval parameters in the whole core. The HI values ranged from 175 to 361 mgHC.g ${ }^{-1}$ TOC, the OI values from 109 to $189 \mathrm{mgCO}_{2} \cdot \mathrm{g}^{-1}$ TOC and the TOC (\%) from 9.3 to $15.4 \%$. In this section, the GelAOM contents were generally higher than those of the FlAOM (on average 8.0 and $6.9 \mathrm{mg} \cdot \mathrm{g}^{-1} \mathrm{sed}$, respectively). At $2050 \mathrm{cal} \mathrm{yr} \mathrm{BP}$, the FlAOM contents exhibited the lowest value in the core $\left(0.7 \mathrm{mg} \cdot \mathrm{g}^{-1} \mathrm{sed}\right)$, whereas the GelAOM reached $10.1 \mathrm{mg} \cdot \mathrm{g}^{-1}$ sed. In the meantime, the amounts of algae, membranes, and opaque debris were variable (2.8 and $4.8 \mathrm{mg} \cdot \mathrm{g}^{-1} \mathrm{sed}$, respectively). During phase D (2050 to 1830 cal $\mathrm{yr}$ BP), the FlAOM content increased, whereas the GelAOM decreased (on average, 12.8 and $4.7 \mathrm{mg} \cdot \mathrm{g}^{-1}$ sed respectively). Slight changes in the quantity (TOC) and in the quality (HI) of the OM were observed as well as an increase in structured organic particles. The HI values followed the evolution of the TOC profile, with values ranging from 252 to $426 \mathrm{mgHC}^{-1} \mathrm{~g}^{-1} \mathrm{TOC}$ and 10.3 to $13.6 \%$, respectively. This phase was marked by a small and especially short-term variability in all parameters, accompanied by relatively low OI values $\left(120 \mathrm{mgCO}_{2} \cdot \mathrm{g}^{-1} \mathrm{TOC}\right.$, on average).

Phase C (1830 to 1550 cal yr BP) was marked by a slight increase in GelAOM and FlAOM as well as in structured organic particles. A decrease in quantity and a change in quality of the OM (TOC and HI, respectively) were also noticed. This phase was marked by low HI and TOC values (on average, $258 \mathrm{mgHC} \cdot \mathrm{g}^{-1} \mathrm{TOC}$ and $10.6 \%$, respectively), with a notable increasing upward trend for both parameters. For phase B (1550 to 1470 cal yr BP), the Rock Eval profiles displayed similar profiles in comparison to phase D. The HI values (on average $361 \mathrm{mgHC} \cdot \mathrm{g}^{-1} \mathrm{TOC}$ ) and TOC (12 to 15\%) were relatively high, whereas the OI values varied between 106 and 142 $\mathrm{mgCO}_{2} \cdot \mathrm{g}^{-1}$ TOC. The GelAOM and LCO contents increased, whereas the FlAOM decreased. Phase A (1470 to 570 cal yr BP) was marked by a slight increase in FlAOM 
with a simultaneous decrease in GelAOM. Membranes (Mb) and Algal OM also increased toward the top of the core. The HI and OI values as well as the TOC contents increased slightly toward the top of the core, namely from 302 to $387 \mathrm{mgHC} . \mathrm{g}^{-1} \mathrm{TOC}$, 120 to $160 \mathrm{mgCO}_{2} \cdot \mathrm{g}^{-1} \mathrm{TOC}$ and 14 to $18 \%$, respectively.

\section{Discussion}

\subsection{Organic Matter origin and preservation}

Rock-Eval pyrolysis has frequently been used to characterize recent sediment records for palaeoenvironmental reconstructions (e.g., Talbot and Livingstone, 1989; Sifeddine et al., 1994, 1998; Ariztegui et al., 2001; Lüniger and Schwark, 2002; Jacob et al., 2004; Disnar et al., 2008). Despite a high correlation ( $\mathrm{R}=0.91$; Fig. 4a), the TOC and TC values present a difference that cannot be explained only by the presence of inorganic carbon because is present at rather stable values between 0.5 and $1 \%$. As assumed by Disnar et al. (2003), this discrepancy can be attributed to a rather low response from the FID detector during the Rock-Eval upon pyrolysis of recent oxygenrich OM. Some clay minerals (especially illite) can also produce artefacts when determining the S2 parameter and the related HI values (Ariztegui et al., 2001). In the present case, such a mineral matrix effect is certainly negligible because of generally high TOC contents and the absence of illite (Caquineau, personal communication). Having considered, but rejected such explanations, the HI and OI variability can be used to estimate the source and/or OM preservation state for the paleoenvironmental assessment.

In a S2 versus TOC diagram (Fig. 4b) all of the samples fall within the field of Type II OM, except two samples from Phase E, which present more terrestrial characteristics (type III). This figure shows a gradual progression between the phases going from phase $\mathrm{E}$ to $\mathrm{A}$, with some phase $\mathrm{C}$ points appearing before most of those of phase D, which thus delineates major changes during that time. In the pseudo-van Krevelen diagram (HI vs. OI), most data points were located in an area of mixed type II - type III OM in variable proportions (Fig. 5a). The HI and OI variability, which is represented by the scatter size for each group, decreased towards the top of the core. During phase E, the OM was characterised by high variability, ranging between type II and III but, with a slight shift towards type III. During phase D, the OM was also oscillating between type II and III, but with a shift toward type II during its middle part. Jacob et al. (2004) used a crossplot of S3 vs. TOC to evaluate the OM's preservation 
state in Lake Caçó, which is $700 \mathrm{~km}$ west of Lake Boqueirão. The same diagram plotted for our sediments (Fig. 5b) indicated better OM preservation in Boqueirão than in Caçó for the Holocene sediments (higher S3 in Lake Caçó for the same TOC values). This difference may be as a consequence of a lower rate of sedimentation and more sandy sediment in Lake Caçó (Sifeddine et al., 2010). Phase E was globally characterized by high S3 values (in samples of $\mathrm{TOC}<12 \%$ ) indicating again poor preservation of terrestrial OM origin during this phase. Phase $\mathrm{E}$ was rich in GelAOM indicating that a strong contribution from terrestrial $\mathrm{OM}$ came from either the margins or the catchment area of the lake. In Fig. 5b, there was a gradual progression from phase $\mathrm{E}$ to phase A, which was marked by an increase in TOC and S3 values, indicating the progressive increase of $\mathrm{OM}$ preservation.

\subsection{Paleoenvironmental interpretations}

The paleoenvironmental and paleohydrological changes that affected Lake Boqueirão during to late Holocene can be examined in light of the five phases observed during the analyses of core Boqc0701.

- Phase E (3000 to 2050 cal yr BP): rapid switches from dry to wet events.

Phase E presents the largest TOC, HI and OI fluctuations recorded along the entire core. The most probable cause of these variations is a great instability in the lake level during this period. High HI and low OI values indicate the presence of well-preserved OM, whereas the FlAOM content indicates sub-aquatic degradation of higher plant remains. This material might have derived from submerged or emersed aquatic macrophytes and their associated epiphytes (Jacob, 2003). The fact that the FlAOM and GelAOM contents are switches the same order indicates the equivalent importance of both allochthonous and autochthonous organic inputs. Rock Eval parameters were interpreted as reflecting a low lake level, instability and the closeness of the margin to the sampling location. The geochemical parameters suggest that there were episodes of more pronounced drought (2780, 2430 and 2230cal yrs BP). During these events of low lake level, the main source of OM supply to the lake was the drainage basin. The last of these driest episodes marks the end of Phase $\mathrm{E}$ and is characterized by a strong decrease in FlAOM content.

- Phase D (2050 to 1830 cal yrs BP): characterized by a high water level.

Phase D was marked by an increase in sedimentation rate. High HI and TOC values together with low OI indicated a higher contribution of a well-preserved OM with a 
probable algal origin. This interpretation is corroborated by an increase in algal OM in the organic petrography. At the same time membranes and FlAOM increased, which reflects the presence of well-developed margin vegetation. All of these parameters correspond to a higher and more stable lake level.

- Phase C (1830 to 1550 cal yrs BP): lowering of the water level.

The sedimentation rate decreased. Both amorphous OM (FlAOM and GelAOM) and recognizable structures of OM - both autochthonous (Membrane, AmLC and algae) and allochthonous (LCO and DO) - decreased, which probably indicates a lower OM sedimentation. This interpretation is corroborated by the low TOC contents. The low HI and high OI values indicate the input of OM that is oxidized, more degraded, and more detrital, which reflects a lower lake level.

- Phase B (1550 to 1470 cal yr BP): Rise of the water level and development of macrophyte communities.

The geochemical and petrographical OM characteristics are similar to Phase D. The FlAOM content increased reflecting a higher lake level. The membrane content was low, which probably reflects a larger distance between the sampling site and the macrophytic belt. The quality and quantity of $\mathrm{OM}$ (HI and TOC) increased, corroborating a more algal contribution.

- Phase A (1470 to 570 cal yr BP): stable lacustrine environment.

During most of this phase, the sedimentation rate remained low except at its end. The HI, OI and TOC were very stable with a slight increasing trend towards the top. For the first time in this record, the OI and HI showed the same trend. The high stability of the proxies during this phase may be due to a persistent deep environment, where OM fluctuations, which were due to changes in the proportion of marginal vegetation contribution during the preceding phases, were strongly buffered. In contrast, organic petrography points to marked changes during this phase. There is, in particular, an increasing trend of all organic material at the end of the record. The low resolution of these analyses does not allow further interpretation of this phase. Finally, it is important to note that the phase ended with a sedimentation hiatus, which was probably due to a drying episode for the lake. This dry phase extended until the last few decades, as reported by local inhabitants.

\subsection{Comparison with other paleoclimate studies}

Several studies have demonstrated that tropical South America was dryer during 
the middle Holocene (e.g., Seltzer et al., 2000; Haug et al., 2001, Turcq et al., 2002, Abbot et al., 2003; Mayle et al., 2008, Cruz et al., 2005, 2009, Cordeiro et al., 2008). This situation was due to a weakening of the South American monsoon forced by lower austral summer insolation (Valdés, 2000). In contrast, our study region of Northeast Brazil had a more humid climate during the early and middle Holocene (Cruz et al., 2009). This could be due to a larger ITCZ belt (northern position during boreal summer and southern position during austral summer; Dias et al., 2009) and a reduced atmospheric subsidence over Northeast Brazil that was driven by the reduced convection in the South American Monsoon regions (Cruz et al., 2009). In this context, our record represents the last part of the Holocene's drying trend in Northeast Brazil.

The Boqc0701 core began with a period of high variability in the climate proxies, which was certainly due to a high variability in the lake level between 3000 and 2050 yrs BP. The Boqueirão variability coincided with the period of high variability in the titanium concentration in the Cariaco basin (Haug et al., 2001). The Ti content in the Cariaco Basin sediment is a proxy for precipitation in the northern part of South America. In this region, precipitation occurred in the boreal summer and was linked to a northern position of the ITCZ. Therefore, the Cariaco record registered the position - or the intensity - of the ITCZ during the boreal summer. The long-term trend of this position shifted toward the South during the Holocene (Haug et al., 2001). The high variability in the Ti contents between 3800 and $2300 \mathrm{yrs}$ cal BP was interpreted as an increase in the ENSO variability. Indeed, during El Niño events, the warmer East Pacific waters displaced the ITCZ's boreal position to the South (Fedorov \& Philander, 2000) causing a deficit in precipitation in Venezuela. On the other hand, El Niño also provoked and intensified the atmospheric subsidence over Northeast Brazil as well as a decrease in precipitation in the region. Another record of past El Niño events has been proposed by Moy et al. (2002) based on the reconstruction of intense rainfall events in the Ecuadorian Lake Pallcacocha. The reconstruction indicates a frequent occurrence of El Niño events between 3500 and 2600 cal yrs BP. It seems that the period of high variability in Lake Boqueirão ended later than in the two other records, but there is uncertainty in the timing on the order of 200-300 yrs (Fig. 1).

In Lake Boqueirão, two phases of high lake level (D and B) were recorded from 2050 to 1830 and from 1550 to 1470 cal yrs BP. In the Pallcacocha records, these were periods of few El Niño occurrences, which would be in agreement with a wetter 
Northeast Brazil. Nothing special appears in the Cariaco record during these periods. In Lake Titicaca (Baker et al, 2005), these two periods are also marked by high lake levels. Baker et al. (2005) observed that the lake level variations at a centennial to millennial scale in Lake Titicaca were correlated to Bond events. These authors hypothesised that during Bond events; the colder temperature of the Northern Hemisphere due to the decrease in the Atlantic Meridional Overturning Circulation (AMOC), reduced the interhemispheric temperature gradient and displaced the ITCZ to the south increasing the precipitation at Lake Titicaca. Indeed, Atlantic variability is today a greater forcing on Northeast Brazil precipitation than El Niño (Hastenrath, et al. 2006). Again, the ${ }^{14} \mathrm{C}$ uncertainties, in all of the records, do not allow discrimination between the ENSO and the Atlantic ITCZ as the main driver of the observed climate fluctuation in Northeast Brazil. Both mechanisms may have influenced the precipitation/evaporation budget in the region. The fact that the Cariaco record does not show any change at that time would also mean that the northern and southern positions of the ITCZ could present independent variations in the past.

During phase A (1050 - 570 cal yrs BP), we observed a great stability in the climate proxies. This finding is surprising because the Cariaco and Pallcacocha records show variations at that time. Although climate stability cannot be discarded, more likely, this phase, perhaps because of the core's. This could be due to the core's greater distance from the lake margin. Indeed, the observed proxy variations were linked to differences between the lake's margin and the open-water OM quality. It is possible that over a certain distance from the lake's margin our coring point was not sensitive to the lake level variations. The sedimentation ended abruptly at 570 cal yrs BP. This termination was due to a drying of the lake, which corresponded to the beginning of the Little Ice Age, LIA (Mann et al., 2009). During this period, the North Atlantic Sea Surface Temperature anomaly (Mann et al., 2009) became negative and remained negative until the $20^{\text {th }}$ century driving a negative anomaly of the North Atlantic Oscillation (Trouet et al., 2009; Mann et al., 2009). This period matches Lake Boqueirão's dry period, although a cold North Atlantic should have brought the ITCZ to the south and should have entailed more precipitation in the Boqueirão region. The Cariaco record indicated lower precipitation during the LIA, which was interpreted as a southward shift in the ITCZ (Haug et al., 2001). It seems again that the boreal and austral positions of the ITCZ did not move similarly in that phase. A decrease in precipitation in the northern and southern tropics of South America during the LIA 
could correspond to an intensification in the El Niño anomaly. This interpretation is in line with Trouet et al. (2009) who described the Medieval Warm Period (MCA) as a permanent La Ninã. Nonetheless, the Pallcacocha record has shown intense El Niño activity during the MCA and to a lesser degree, during the LIA. An increase on precipitation in the eastern side of the Andes during the LIA was suggested due to the low values of $\delta^{18} \mathrm{O}$ in the Quelccaya Ice Cap (Thomson et al., 1986) as well as the Cascayunga (Reuter et al., 2009) and Pumacocha (Bird et al., 2011) caves in Peru. This increase could have been due to an intensification in the South American monsoon that is related to a southern shift in the ITCZ (Bird et al., 2011). However, the Lake Boqueirão data indicated a dry LIA and therefore, no southward shift in the ITCZ at that time. In contrast, the South American Monsoon intensification can cause the observed dryness in the northeast region. An intensification in the monsoon would have accentuated convection in Amazonia and atmospheric downwelling over Northeast Brazil. The intensification of the Northeast high would have kept the ITCZ in a relatively northern position during the Austral summer at least in the western part of tropical Atlantic. A similar mechanism has been proposed by Cruz et al. (2009) for the middle Holocene period, where the Amazon was dryer and the Northeast region was wetter.

\section{Conclusion}

This work allowed us to characterize qualitatively and quantitatively the sedimentary $\mathrm{OM}$ in Lake Boqueirão to provide new insight into the late Holocene climate in the Brazilian Northeast region. The proxies used were TOC, HI and OI of the bulk sediment and organic petrography counts. HI and OI varied according to the origin and preservation of the OM, which allowed differentiation of open-water well-preserved OM from margin macrophytic vegetation. Between 3000 and 1050 cal yrs BP, fluctuations of these proxies were interpreted in terms of lake level variations. During the last recognized phase (1050 to 570 cal yrs BP), these proxies remained very stable, most probably because the conditions at the coring site did not change much at that time. Other analyses, such as molecular organic geochemistry, might provide further information about that last phase of sedimentation.

From 3000 to $2050 \mathrm{cal} \mathrm{yrs}$ BP, the lake level fluctuated dramatically. Two wet phases were found at 2050-1830 and 1550-1470 yrs BP. These changes in lake level can 
be compared with other high-resolution records from tropical South America during the late Holocene. Although correlations were limited by ${ }^{14} \mathrm{C}$ uncertainty, it seems that there was a good correspondence between the phases of low ENSO and cool North Atlantic and Boqueirão wet phases. We did not encounter the same pattern during the last 1050 years, during which the 1050-570 interval was generally wet (although probable fluctuations were buffered in our proxies). A prolonged dryness occurred since the beginning of the LIA, at $570 \mathrm{cal}$ yrs BP, until recent decades. Therefore, it appears that the teleconnection pattern involving the ENSO and the Atlantic ITCZ changed at that time. This pattern could be a strong limitation for the reconstruction of past climate mechanisms, e.g., ITCZ shifts or ENSO fluctuations, because most of the continental proxies were related to precipitation and not directly to atmospheric circulation. The driving mechanisms of precipitation may have changed in the past and Lake Boqueirão appears to be a good example of that. The proximity of the Atlantic Ocean may have also influenced the observed precipitation changes. High-resolution records and other analyses such as biomarkers are necessary to better understand climate fluctuations in this region over the last few millennia.

\section{Acknowledgements}

This work was supported by the Universidade Federal Fluminense (Brazil), LOCEAN (UMR UPMC/IRD/CNRS/MNHN) and ISTO (UMR Université d'Orléans/CNRS). This project was developed within the PALEOTROPICA Project (IRD,France/CNPq Brazil) and Paleotrace LMI (IRD) by two frameworks of cooperation between the Environmental Geochemistry Program-UFF and IRD-France. This paper contributes to the ESCARSEL project funded by the French National Agency of Research (program VMC, project ANR-06-VULN-010) and ANR ELPASO (2008 blanc 60801). Carbon-14 data were obtained at the "Laboratoire de mesures du ${ }^{14}$ C" UMS 2572 LMC14 (CEA/CNRS/IRD/IRNS/MCC) for ${ }^{14} \mathrm{C}$ data. The authors acknowledge CNPq project 482837/2009-8 "Interconexões entre mudanças paleoclimáticas, o sistema de monção sul americana e distúrbios relacionados ao fogo em sistemas florestais". The authors also wish to thank the reviewers for their constructive remarks on a previous version of the manuscript.

\section{References:}


Abbot, M.B., Seltzer, G.O., Kelts, K.R., Southon, J., 2003. Holocene paleohydrology and glacial history of de central Andes using multiproxy lake sediments studies. Palaeogeogr. Palaeoclimatol. Palaeoecol. 194, 123-138.

Ariztegui, D., Chondrogianni, C., Lami, A., Guilizzoni, P., Lafargue, E., 2001. Lacustrine organic matter and the Holocene palaeoenvironmental record of Lake Albano (central Italy). J of Paleolimn. 26, 283-292.

Arz, H.W., Patzold, G., Wefer G., 1999. Climatic changes during the last glaciation recorded in sediment cores from the northeastern Brazilian Continental Margin. Geo-Marine Lett. 19: 209-218.

Arz, H.W., Lamy, F., Ganopolski, A., Nowaczyk, N. and Pätzold, J., 2007. Dominant Northern Hemisphere climate control over millennialscale glacial sea-level variability, Quat Sci Rev. 26(3-4): 312-321.

Baker, P.A., Fritz, S.C., Garland, J., and Ekdahl, E.J., 2005. Holocene hydrologic variation at Lake Titicaca, Peru/Bolivia, and its relation to North Atlantic climate variation. Journal of Quaternary Science 20, 655-62.

Bird, B.W., Abbott, M.B., Vuille, M., Rodbell, D.T., Stansell, N.D., and Rosenmeier, M.F. 2011. A 2,300-year-long annually resolved record of the South American summer monsoon from the Peruvian Andes. Proceedings of National Academy of Science www.pnas.org/cgi/doi/10.1073/pnas.1003719108.

CEPALC, Rapport des Nations Unies. L'économie du changement climatique en Amérique latine et dans les Caraïbes - Synthèse 2009. Publication Nations Unies.

Cole, M.M., 1960. Cerrado, caatinga and pantanal: distribution and origin of the savanna vegetation of Brazil. Geographical Journal. 126, 168-179.

Cheng H., Fleitmann, D., Edwards, R.L., Wang, X., Cruz, F., Auler, A., Mangini, A. Wang, Y., Kong, X., Burns, S.J., Matter, A., 2009. Timing and structure of the 8.2 kyr B.P. event inferred from $\delta 180$ records of stalagmites from China, Oman, and Brazil. Geology 37:11, 1007-1010.

Cordeiro, R. C., Turcq, B., Suguio, K., Silva, A.O., Sifeddine, A., Volkmer-Ribeiro, C., 2008. Holocene fires in east Amazonia (Carajás), new 100 evidences, chronology and relation with paleoclimate. Global and Planetary Change 61, 49-62.

CPRM - Serviço Geológico do Brasil, 2012. Folhas SB.25 Natal e Sc. 25 Recife (formação ENb). http://mapoteca.cprm.gov.br/programas/template.php\#. Access March, 2012. 
Cruz, F. W., Burns, S.J., Karmann, I., Sharp, W.D., Vuille, M., Cardoso, A.O., Ferrari, J.A., Dias, PL.S., Viana, O., 2005. Insolation-driven changes in atmospheric circulation over the past 116,000 years in subtropical Brazil. Nature 434, 63-66.

Cruz, F.W., Vuille, M., Burns, S.J, Wang, X., Cheng, H., Werner, M., Edwards, R.L., Karmann, I. Auler, A.S., Nguyen, H., 2009. Orbitally driven east-west antiphasing of South American precipitation. Nature Geosc. 22 ,1-5.

Disnar, J.R., Guillet, B., Kéravis, D., Di-Giovanni, C., Sebag, D., 2003. Soil organic matter (SOM) characterisation by Rock- Eval pyrolysis: scope and limitations. Org. Geochem. 34, 327- 343.

Disnar, J.R., Jacob, J., Morched-Issa, M., Lottier, N., Arnaud, F., 2008. Assessment of peat quality by molecular and bulk geochemical analysis: Application to the Holocene record of the Chautagne marsh (Haute Savoie, France). Chem Geol. 254,101-112.

Eiten, G., 1982. Brazilian "Savannas”. In: Huntley, B.J., Walker, B.H. (Eds.), Ecology of Tropical Savannas. Ecological Studies, Vol. 42. Springer, Berlin, pp. 25-47.

Fedorov \& Philander, 2000. Is El Niño Changing? Science. 288, 1997-2002.

Hastenrath, H., 2006. Circulation and teleconnection mechanisms of Northeast Brazil droughts. Progress in Oceanog. 70, 407-415.

Haug, G.H., Hughen, K.A., Sigman, D.M., Peterson, L.C., Peterson, L.C., Röhl, U., 2001. Southward migration of the Intertropical Convergence Zone through the Holocene. Science 293, 1304-1308.

Hui, F., Gasse, F., Huc, A., Yuanfang, L., Sifeddine, A., Soulié-Marsche, I., 1995. Holocene environmental changes in Bangong basin (Western Tibet). Part 3: biogenic remains. Palaeogeogr., Palaeoclimatol., Palaeoecol. 120, 65-78.

IBGE, 1993. Mapa de Vegetação do Brasil, Rio de Janeiro.

Jacob, J., 2003. Enregistrement des variations paléoenvironnementales depuis 20000 ans dans le Nord Est du Brésil (Lac Caçó) par les triterpènes et autres marqueurs organiques. Ph.D. Thesis, Université d'Orléans, France. p. 296. Available from: <http://tel.ccsd.cnrs.fr/documents/archives0/00/00/29/42/index_fr.html>.

Jacob, J., Disnar, J.R., Boussafir, M., Sifeddine, A., Albuquerque, A.L.S., Turcq, B., 2004. Major environmental changes recorded by lacustrine sedimentary organic matter since the Last Glacial Maximum under the tropics (Lagoa do Caçó, NE Brazil). Palaeogeography, Palaeoclimatology, Palaeoecology 205, 183-197. 
Lafargue, E., Marquis, F., Pillot, D., 1998. Rock-Eval 6 applications in hydrocarbon exploration, production, and soil contamination studies. Rev. Inst. Fr. Pét. 53/4, 421-437.

Lüniger, G., Schwark, L., 2002. Characterisation of sedimentary organic matter by bulk and molecular geochemical proxies: an example from an Oligocene maar-type Lake Enspel, Germany. Sediment. Geol. 148, 275- 288.

Mann, M.E., Zhang, Z., Rutherford, S., Bradley, R.S., Hughes, M.K., Shindell, D., Ammann, G. Faluvegi, G., Ni, F., 2009. Global Signatures and Dynamical Origins of the Little Ice Age and Medieval Climate Anomaly. Science 236:1256-1260.

Mayle, F.E., Power, M.J., 2008. Impact of a drier Early-mid-Holocene climate upon Amazonian forests. Philosophical Transactions 363, 1829-1838.

Moy, C.M., Seltzer, G. O., Rodbell, D.T., Anderson, D.M., 2002. Variability of El Niño/Southern Oscillation activity at millenial timescales during the Holocene epoch. Nature 420, 162-164.

Nobre P., Shukla J., 1996. Variations of sea surface temperature, wind stress and rainfall over the tropical Atlantic and South America. J of Climate. 9, 2464-2479.

Patience, A.J., Lallier-Vergès, E., Sifeddine, A., Albéric, P., Guillet, B., 1995. Organic fluxes and early diagenesis in the lacustrine environment: the superficial sediments of the Lac du Bouchet (Haute Loire, France). In: Lallier-Vergès, E., Tribovillard, N.P., Bertrand, P. (Eds.), Organic Matter Accumulation: The Organic Cyclicities of the Kimmeridge Clay Formation (Yorkshire, GB) and the Recent Maar Sediments (Lac du Bouchet, France). Springer-Verlag, Heidelberg, pp. 145-156.

Reuter, J., Stott, L., Khider, D., Sinha, A., Cheng, H., and R.L. Edwards. 2009. A new perspective on the hydroclimate variability in northern South America during the Little Ice Age. Geophysical Research Letters, VOL. 36, L21706, doi:10.1029/2009GL041051,

Seltzer, G., Rodbell, D., Burns, S., 2000. Isotopic evidence for a late quaternary climatic change in tropical South America. Geology 28, 35-38.

Sifeddine, A., Bertrand, P., Fournier, M., Martin, L., Servant, M., Soubies, F., Suguio, K., Turcq, B., 1994. La sédimentation organique lacustre en milieu tropical humide (Carajás, Amazonie orientale, Brésil): relation avec les changements climatiques au cours des 60000 dernières années. Bulletin de la Société Géologique de France 165 (6), 613-621. 
Sifeddine, F., Laggoun-Défarge, F., Lallier-Vergès, E., Disnar, J.R., Williamson, D., Gasse, F., Gibert, E., 1995. La sédimentation organique lacustre en zone tropicale sud au cours des 36000 dernières annèes (Lac Tritrivakély, Madagascar). C.R. Acad. Sci. Paris, Ser. IIa 321, 385- 391.

Sifeddine, A., Bertrand, P., Lallier-Vergès, E., Patience, A.J., 1996. Lacustrine organic fluxes and palaeoclimatic variations during the last $15 \mathrm{ka}$ : Lac du Bouchet (Massif Central, France). Quat. Sci. Rev. 15, 203- 211.

Sifeddine, A., Bertaux, J., Mourguiart, P., Martin, L., Disnar, J.R., Laggoun-Défarge, F., Argollo, J., 1998. Etude de la sédimentation lacustre d'un site de forêt d'altitude des Andes centrales (Bolivie). Implications paléoclimatiques. Bulletin de la Société Géologique de France 169 (3), 395-402.

Sifeddine, A., Meyers, P., Cordeiro, R., Albuquerque, A., Bernardes, M., Turcq, B., Abrão, J., 2010. Delivery and deposition of organic matter in surface sediments of Lagoa do Caçó (Brazil). J of Paleolimn. 45:3, 385-396.

Stuiver, M., Reimer, P.J., Reimer, R., 2009. Calib, Version 5.02. <http://calib.qub.ac.uk/calib/>.

Talbot, M. R., Livingstone, D. A. 1989. Hydrogen index and carbon isotopes of lacustrine organic matter as lake level indicators. Palaeogeogr., Palaeoclim., Palaeoecol. 70: 121-137.

Thomson, L.G., Thomson, E.M., Dansgaard, W., Groots, P.M. 1986. The little Ice Age as recorded in stratigraphy of the tropical Quelcaya Ice Cap. Science 234:361-364.

Trouet,V., Esper, J., Graham, N.E., Baker, A., Scourse, J.D., Frank, D.C., 2009. Persistent Positive North Atlantic Oscillation Mode Dominated the Medieval Climate Anomaly. Science 324, 78-80.

Turcq, B., Albuquerque, A.L.S., Cordeiro, R.C., Sifeddine, A., Simões Filho, F., F.L.A., Souza, G., Abrão, J.J., Oliveira, F.B.L., Silva, A.O., Capitâneo, J.A., 2002. Accumulation of organic carbon in five Brazilian lakes during the Holocene. Sedimentary Geology 148, 319-342.

Valdés, P. J., 2000. South American paleoclimate model simulations: how reliable are the models? J. of Quat Sci.15:4, 357-368.

Zocatelli, R., Jacob, J., Turcq, B, Boussafir, M., Sifeddine, A. Bernardes, M.C., 2010. Molecular evidence for recent turf cultivation in Northeast Brazil (Lagoa do Boqueirão, RN State). Org Geochem. 41, 427-430. 


\section{Figure Captions:}

Fig. 1 - Map of study area, including Lake Boqueirão with its surrounding basin and location of coring site (a). Seismic profile (b) and radiocarbon chronology showing the ${ }^{14} \mathrm{C}$ conventional and calibrated (cal yrs BP) ages (c).

Fig. 2 - Description of the main organic classes identified to organic petrography of Lake Boqueirão sediments.

Fig. 3 - Downcore variations in $\mathrm{OM}$ abundance and composition deduced from elementary analyses and the distribution of the main organic classes identified in the organic petrography (mg/gsed). The HI, OI and TOC parameters evaulated in the RockEval6 Turbo and TC contents by Elementar analyser.

Fig. 4 - Correlation between the TOC content (\%) determined by Rock-Eval pyrolysis and TC contents (\%) determined by classical combustion with the Elementar (Vario EL III) analyser. Dashed line defines the mineral carbon regression line for the entire set of data. (b) S2 vs. TOC diagram. Gray lines define boundaries of organic matter types, whereas the solid line indicates the regression line for the entire set of data.

Fig. 5 - (a) Pseudo van-Krevelen type diagram for Lake Boqueirão's OM sediments and (b) correlation of the Rock-Eval parameters of $\mathrm{S} 3=\mathrm{S}_{3} \mathrm{CO}_{2}=\mathrm{f}(\mathrm{TOC})$. 
Figure 1

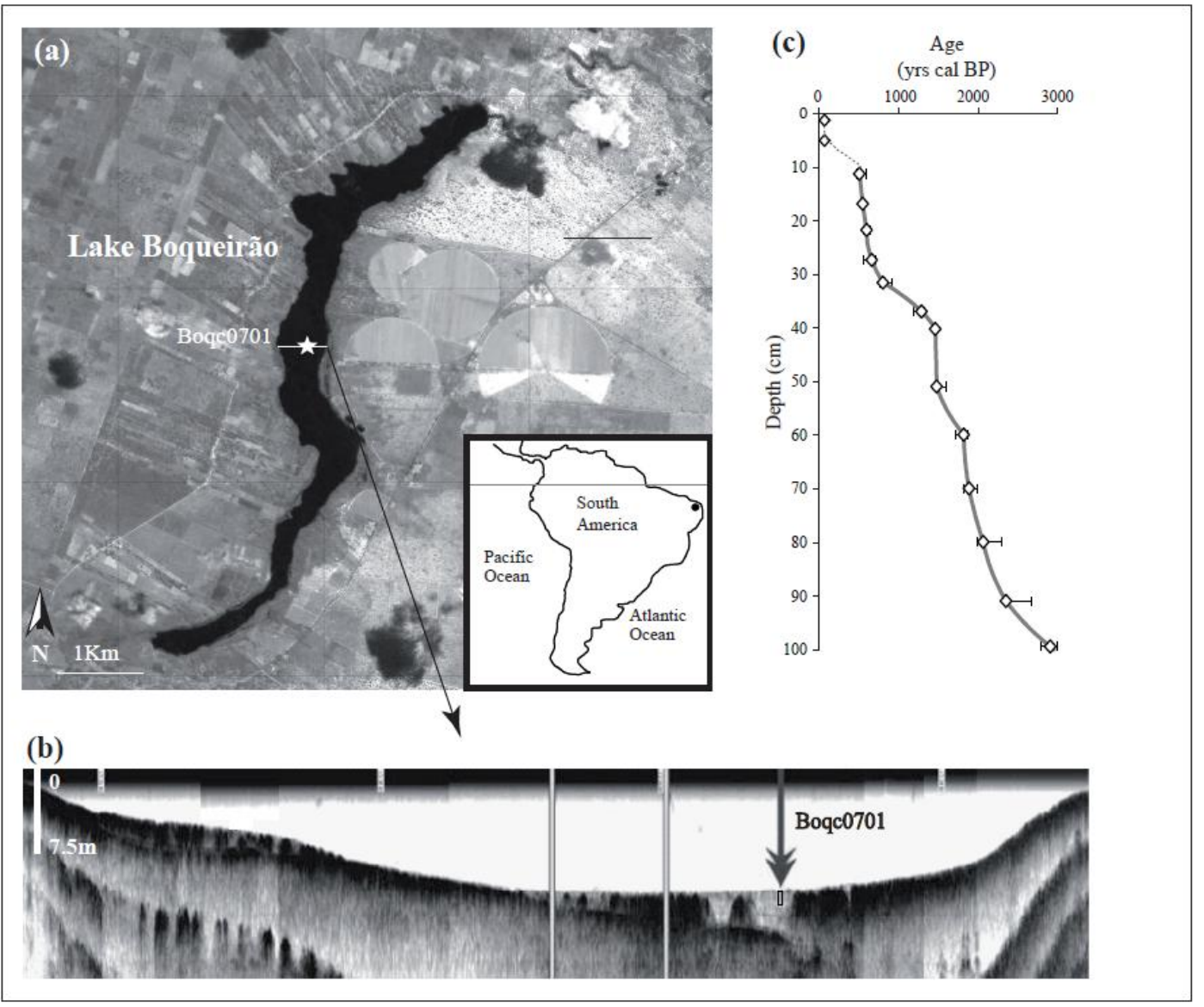


Figure 2

\begin{tabular}{|c|c|c|c|c|c|c|c|}
\hline $\begin{array}{l}\text { Type of } \\
\text { organic matter } \\
\text { constituent }\end{array}$ & $\begin{array}{l}\text { Flarky } \\
\text { amorphous } \\
\text { OM }\end{array}$ & $\begin{array}{l}\text { Gelified } \\
\text { amorphous } \\
\text { OM }\end{array}$ & $\begin{array}{l}\text { Translucent } \\
\text { ligno-cellulosic } \\
\text { debris }\end{array}$ & $\begin{array}{l}\text { Amorphised } \\
\text { ligno-cellulosic } \\
\text { debris }\end{array}$ & $\begin{array}{l}\text { Opaque ligno- } \\
\text { cellulosic debris }\end{array}$ & Membrane & Algal MO \\
\hline \multirow[t]{2}{*}{$\begin{array}{l}\text { Abbreviation } \\
\text { Illustration }\end{array}$} & FIAMON & GELMON & TrLC & $\mathrm{AmLC}$ & LCO & Memb & Algal MO \\
\hline & $0.05 \mathrm{~mm}$ & $0.05 \mathrm{~mm}$ & $0.05 \mathrm{~mm}$ & $0.05 \mathrm{~mm}$ & $0.05 \mathrm{~mm}$ & $0.05 \mathrm{~mm}$ & $0.05 \mathrm{~mm}$ \\
\hline Description & Difused Edge & Sharp Edge & $\begin{array}{l}\text { Vascular } \\
\text { structures still } \\
\text { present }\end{array}$ & $\begin{array}{l}\text { Progressive } \\
\text { destruction of } \\
\text { biological } \\
\text { structures }\end{array}$ & $\begin{array}{l}\text { Progressive } \\
\text { oxidation of } \\
\text { biological } \\
\text { structures }\end{array}$ & $\begin{array}{l}\text { Fine structure still } \\
\text { present }\end{array}$ & $\begin{array}{l}\text { Algal } \\
\text { micro-colonies }\end{array}$ \\
\hline Main features & $\begin{array}{l}\text { Heterogeneous } \\
\text { texture }\end{array}$ & $\begin{array}{l}\text { Homogeneous } \\
\text { texture }\end{array}$ & $\begin{array}{l}\text { Translucent } \\
\text { texture }\end{array}$ & $\begin{array}{l}\text { Ligno-cellulosic } \\
\text { texture }\end{array}$ & Opaque texture & & \\
\hline Possible origin & $\begin{array}{l}\text { Submerged or } \\
\text { emergent high } \\
\text { plants }\end{array}$ & $\begin{array}{l}\text { Terrestrial high } \\
\text { plants }\end{array}$ & High plants & High plants & High plants & $\begin{array}{l}\text { Submerged or } \\
\text { emergent high } \\
\text { plants }\end{array}$ & Phyto planktonic \\
\hline $\begin{array}{l}\text { Main depositional } \\
\text { environment }\end{array}$ & Lacustrine & Palustrine & $\begin{array}{l}\text { Paludal incresing } \\
\text { degradation }\end{array}$ & $\begin{array}{l}\text { Paludal incresing } \\
\text { degradation }\end{array}$ & $\begin{array}{l}\text { Paludal incresing } \\
\text { oxidation }\end{array}$ & $\begin{array}{l}\text { Marginal } \\
\text { lacustrine }\end{array}$ & lacustrine \\
\hline
\end{tabular}




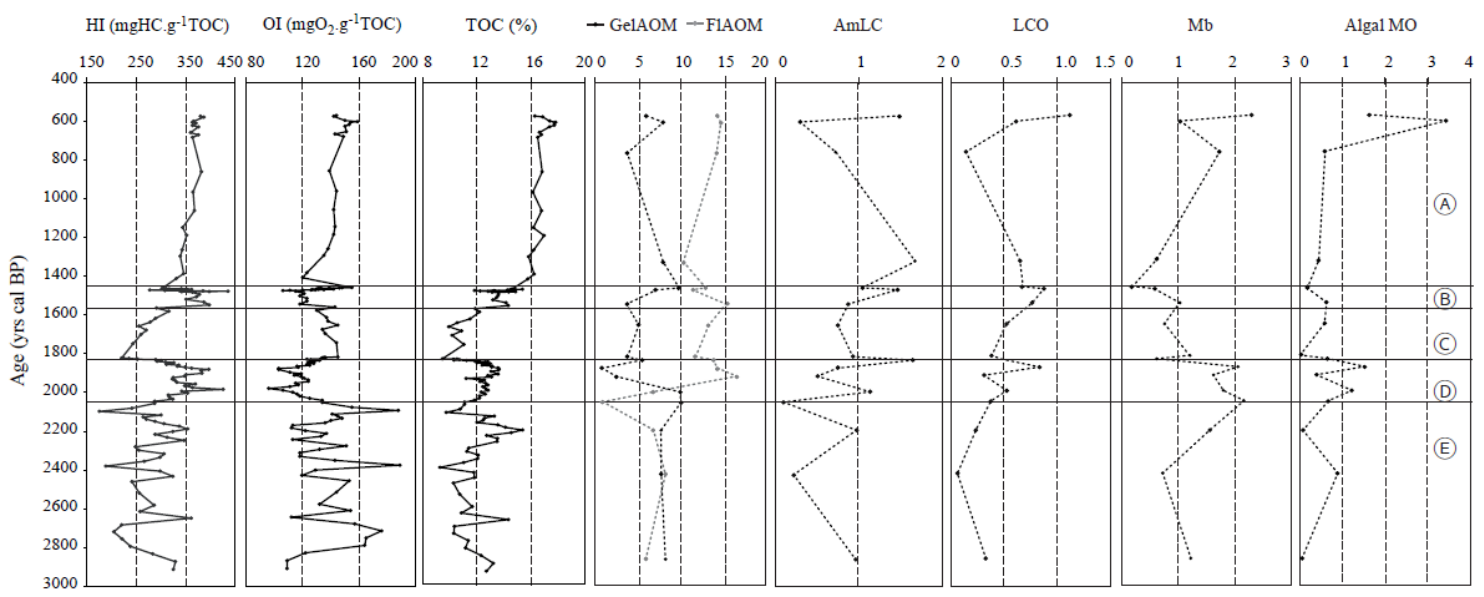


Figure 4
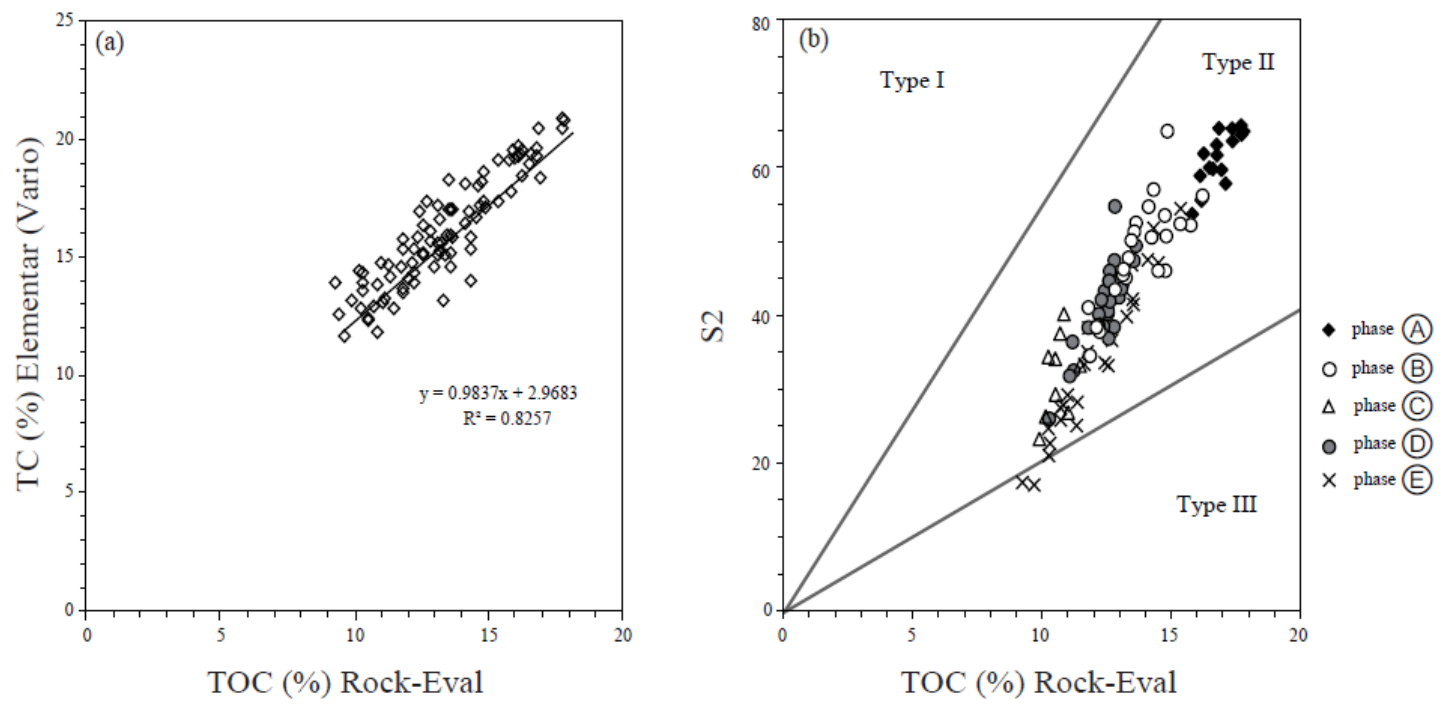
Figure 5

- phase (A) $\circ$ phase (B) $\Delta$ phase (C) $\circ$ phase (D) $\times$ phase (E)
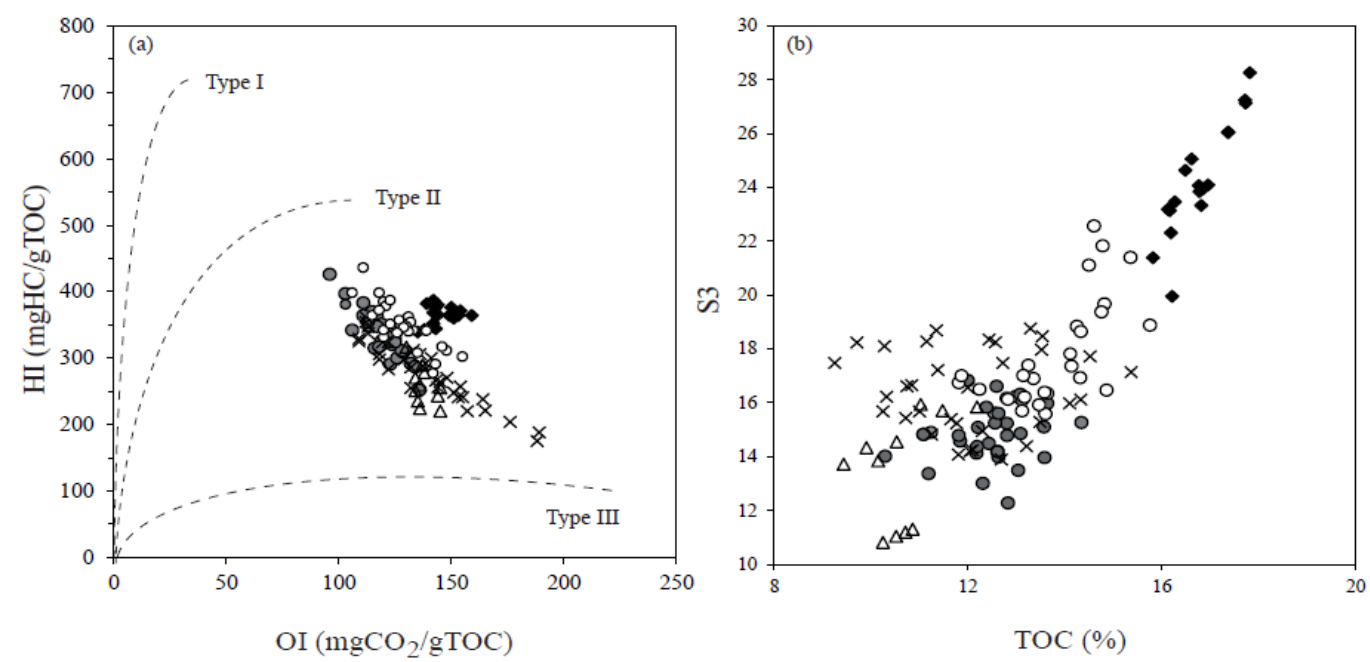


\section{Highlights (85 words)}

> We studied sediments of Lake Boqueirão, Northeast Brazil.

> This region experiences ITCZ displacement and represents a key location to study Holocene environmental changes in South America.

$>$ Between 3000 and 1050 calyrsBP, proxies showed fluctuations interpreted as lake level variations.

$>$ From 1050 to 570 calyrsBP, proxies remained stable, probably due the stable conditions at the coring site.

$>$ A prolonged dryness occurred since 570 calyrsBP, until the latest decades that correspond to the Little Ice Age event. 